\title{
Manfaat Proloterapi pada Osteoartritis Lutut
}

\author{
Gracia V. Y. Deeng, Sekplin A. S. Sekeon, Finny Warouw
}

\author{
${ }^{1}$ Program Studi Pendidikan Dokter Fakultas Kedokteran Universitas Sam Ratulangi, Manado, \\ Sulawesi Utara, Indonesia \\ ${ }^{2}$ Bagian Neurologi Fakultas Kedokteran Universitas Sam Ratulangi, Manado, Sulawesi Utara, \\ Indonesia \\ Email: graciavini31@gmail.com
}

\begin{abstract}
Osteoarthritis (OA) is calcification of the joint associated with severe painful sensation caused by joint instability. This joint instability is affected by destruction of cartilage that protects the bones. Osteoarthritis can be caused by various factors such as age, genetic as well as vigorous exercise or activity. As the cartilage destruction progresses, the unprotected bone will rub on the other bone in the joint which can lead to osteoarthritis. Management of OA consists of a variety of treatments, such as pharmacological, non-pharmacological, non-pharmacotherapy, and surgery treatments. Due to the development of science and technology, various modalities have emerged that can support the treatment of OA inter alia prolotherapy. Prolotherapy or regenerative injection could influence the recovery of the destructed area directly and relief the painful sensation through the actions of inflammatory cells, macrophages, immune cells, and cytokines, therefore, the improvement of the destructed areas could occur faster. It was reported that knee osteoarthritis could be treated with prolotherapy successfully. In conclusion, since prolotherapy influences the body to repair the destructed areas, hence it could be used as the new osteoarthritis treatment, especially knee osteoarthritis.
\end{abstract}

Keywords: prolotherapy, knee osteoarthritis, chronic pain

\begin{abstract}
Abstrak: Osteoartritis (OA) merupakan pengapuran sendi yang disertai nyeri hebat, disebabkan oleh karena adanya ketidakstabilan sendi yang dipengaruhi oleh rusaknya tulang rawan yang berperan untuk melindungi tulang. Osteoartritis dapat disebabkan oleh berbagai faktor seperti usia, jenis kelamin, genetik, aktivitas maupun olahraga berat. Saat tulang rawan rusak, maka tulang yang tidak dilindungi dapat saling bersinggungan di sendi sehingga sendi hancur dan berujung pada OA. Pengobatan untuk OA terdiri dari beragam pengobatan baik farmakologi, nonfarmakologi, non-farmakoterapi, maupun tindakan operasi. Seiring berjalannya perkembangan ilmu pengetahuan dan teknologi, maka muncul berbagai modalitas yang dapat menunjang pengobatan OA, antara lain proloterapi. Proloterapi atau injeksi regeneratif memengaruhi dan memberi dampak penyembuhan secara langsung pada area yang mengalami cedera maupun nyeri melalui kerja sel-sel radang, makrofag, sel-sel imun, dan sitokin sehingga dapat bekerja lebih cepat untuk perbaikan daerah yang cedera. Telah dilaporkan hasil bermakna dalam penggunaan proloterapi pada osteoartritis lutut. Simpulan penelitian ini ialah proloterapi merangsang tubuh untuk memperbaiki daerah yang cedera sehingga merupakan solusi terbaik yang dibutuhkan dalam pengobatan OA dewasa ini terutama pada OA lutut.
\end{abstract}

Kata kunci: proloterapi, osteoartritis lutut, nyeri kronik

\section{PENDAHULUAN}

Salah satu penyakit yang tergolong dalam penyakit muskuloskeletal ialah osteoartritis (OA). ${ }^{1}$ Penyakit ini yang paling sering menyerang sendi pada orang dewasa di seluruh dunia. ${ }^{2}$ Prevalensi OA pada dewasa dengan usia 25 tahun sebesar 14\% sedangkan pada orangtua dan yang berusia 
diatas 65 tahun sebesar 34\%. Hasil penelitian membuktikan bahwa kebanyakan dari populasi berusia 65 tahun ke atas memiliki gambaran radiografi dengan osteoarthritis. ${ }^{3}$ Gejala yang timbul pada osteoartritis lutut ialah $16 \%$ pada orang dewasa berusia 45 tahun ke atas, dan sekitar $19 \%$ pada perempuan serta $14 \%$ pada laki-laki. ${ }^{4}$ Osteoartritis lutut selain menimbulkan nyeri yang sangat juga dapat berpengaruh pada kondisi seharihari seseorang, sehingga seseorang menjadi "lumpuh" untuk segala kegiatan yang dilakukan. Penderita OA secara tidak langsung akan menggantungkan hidupnya pada orang di sekitarnya, dan hal tersebut tentu saja membutuhkan biaya. Dengan kata lain, penyakit ini dapat memberikan dampak pada perekonomian, pekerjaan, dan terlebih lagi kualitas hidup serta kesehatan seseorang. ${ }^{2}$

Pengobatan untuk memperbaiki masalah pada penyakit ini sangat beragam. Biasanya orang awam akan meminum parasetamol untuk mengurangi nyeri yang dirasakan. Namun, beberapa hasil penelitian telah menyatakan bahwa parasetamol (asetaminofen) hanya memberikan manfaat sedikit dalam penanganan nyeri OA lutut pada seseorang. ${ }^{5}$ Walaupun obat anti inflamasi non stereoid (OAINS) juga efektif untuk menghilangkan nyeri, namun keamanan akan penggunaan obat ini untuk jangka panjang perlu diperhatikan. Pada dasarnya OAINS bekerja untuk mengurangi nyeri dan bengkak pada jaringan. Obatobatan seperti ibuprofen dan naproxen dapat memperlambat proses peradangan, sehingga jika pasien meminum obat-obatan anti inflamasi ditambahkan injeksi proloterapi, maka proloterapi tidak dapat berfungsi dan bekerja dengan baik. ${ }^{6}$ Terdapat pula pengobatan tradisional dengan cara menyuntikkan kortikosteroid dan obat anti inflamasi ke dalam lutut. Pengobatan dengan cara ini sebenarnya mempercepat proses kematian jaringan-jaringan yang ada dan secara tidak langsung mempercepat proses terjadinya osteoartritis. Sendi akan lebih cepat hancur yang tentunya tidak sesuai dengan yang diharapkan sehingga pengobatan secara tradisional telah ditinggalkan dan dianggap tidak efektif. ${ }^{5}$
Oleh karena itu dibutuhkan suatu cara pengobatan baru, lebih efektif, dengan biaya yang lebih terjangkau dalam penyembuhan penyakit muskuloskeletal, salah satunya ialah OA pada lutut. ${ }^{7}$ Pengobatan terbaru yang sekarang telah memberikan hasil yang cukup bermakna serta membawa hasil yang jauh lebih bermanfaat di bidang kedokteran ialah proloterapi. Proloterapi merupakan teknik injeksi yang berfungsi untuk menstabilisasi sendi, menghentikan sendi-sendi yang mengalami keterbatasan bergerak serta membantu menangani rangsangan saraf. Penggunaan proliferan seperti dekstrosa terbukti efektif dalam penanganan nyeri kronis sehingga dapat digunakan untuk mengatasi rasa nyeri. Dengan kata lain, metode injeksi pada proloterapi bertujuan untuk mengurangi rasa nyeri dengan memengaruhi dan memberikan dampak penyembuhan langsung pada area atau penyebab rasa nyeri. ${ }^{8}$

Bertolak dari latar belakang yang telah dipaparkan maka penulis memandang perlu untuk membahas mengenai proloterapi sebagai pengobatan baru yang terbukti lebih efesien jika ditinjau dari segi biaya, terlebih lagi bila dibandingkan dengan tindakan operasi seperti joint replacement.

\section{METODE PENELITIAN}

Penelitian yang dilakukan berupa suatu literature review. Pencarian data menggunakan tiga database dengan kriteria yang telah ditentukan sebelumnya yaitu, ClinicalKey, Pubmed, Journal of Prolotherapy (JOP), Jurnal Sinaps serta Google Scholar. Kata kunci yang digunakan dalam pencarian baik jurnal dan artikel terkait penulisan literature review ini ialah Knee Osteoarthritis AND Prolotherapy. Berdasarkan hasil pencarian literatur diperoleh artikel sebanyak 2.190 pada Google Scholar, 46 pada Pubmed, 8 pada Journal of Prolotherapy, 1 pada Jurnal Sinaps dan 238 pada ClinicalKey $(\mathrm{n}=2.483)$ yang sesuai dengan kata kunci tersebut. Hasil pencarian ini dilakukan penyaringan berdasarkan judul yang sesuai dengan tema literature review, dan didapatkan 30 artikel $(n=30)$. Selanjutnya, 20 artikel kemudian di tinjau abstrak dan full text berdasarkan 
kriteria inklusi dan eksklusi dan diperoleh 10 artikel $(\mathrm{n}=10)$.

\section{HASIL PENELITIAN}

Jumlah sampel pada penelitian dalam 10 literatur terdiri dari sedikit sampai banyak orang berdasarkan banyaknya penderita yang mengalami OA lutut. Berdasarkan kajian dari kesepuluh literatur, terdapat proliferan yang digunakan dalam injeksi proloterapi disertakan dosis, volume, dan rentang waktu penatalaksanaan penggunaan prloterapi. Berdasarkan data yang disertakan masing-masing peneliti mengenai faktor risiko terhadap OA lutut, setiap literatur memberikan penjelasan manfaat dari penggunaan proloterapi pada OA lutut.

Pada penelitian ini didapatkan 10 literatur yang memenuhi kriteria inklusi dan eksklusi serta merupakan penelitian crosssectional, dengan penelitinya sebagai berikut: Naseer ZA et al tahun $2017,{ }^{4}$ Sit RWS et al tahun $2020,{ }^{5}$ Rabago D et al tahun 2010, ${ }^{8}$ Hauser RA dan Cukla JJ tahun 2009, Reeves DK tahun $2000,{ }^{10}$ Reeves DK et al tahun 2016, ${ }^{11}$ Sekeon SAS et al tahun 2019, ${ }^{12}$ Hauser RA dan Hauser MA tahun 2011, ${ }^{13}$ Wheaton MT dan Jensen N tahun $2011,{ }^{14}$ dan Arias-Vasquez $\mathrm{P}$ et al tahun 2019. ${ }^{15}$

Literatur pertama oleh Naseer et $\mathrm{al}^{4}$ pada tahun 2017 telah dipublikasikan ke dalam Insall \& Scott Surgery of the Knee dengan judul Nonoperative treatment of knee arthritis. Berbagai macam tatalaksana yang dapat dilakukan pada kasus OA lutut, dan proloterapi merupakan salah satu metode yang sudah digunakan sejak 70 tahun silam. Penggunaan injeksi dekstrosa hipertonik ke daerah yang nyeri pada lutut dapat membuat respon inflamasi yang diiringi oleh respon tubuh dalam mengeluarkan mediator-mediator kimiawi yang dapat mempercepat proses regenerasi jaringan yang rusak, memperkuat jaringan ikat, serta meningkatkan biomekanik jaringan sekitar. Dengan pengukuran berdasarkan WOMAC, telah didapatkan hasil bermakna dalam 4 minggu sejak injeksi pertama, dan tetap menunjukkan perkembangan yang progresif selama 1 tahun pemantauan. Dengan demikian, penggunaan proloterapi dalam pena- nganan OA lutut dapat dijadikan metode penatalaksanaan walaupun masih diperlukan penelitian lebih lanjut.

Literatur ke-2 oleh R. Sit et $\mathrm{al}^{5}$ pada tahun 2020 dan dipublikasikan di dalam Annals of Family Medicine dengan judul Efficacy of intra-articular hypertonic dextrose (prolotherapy) for knee osteo-arthritis: a randomized controlled trial. Dengan total 205 partisipan, 76 orang memenuhi standar kriteria dan dikelompokkan kedalam kriteria kontrol dan randomisasi, kemudian dibagi kedalam 2 grup, masing-masing terdiri dari 36 orang dengan rerata usia 63,2 tahun, dan dengan mayoritas wanita sebanyak $73,2 \%$; $21 \%$ di antaranya memiliki kelebihan berat badan dan $46 \%$ dengan obesitas. Pada durasi kisaran 8,9 tahun penderita merasakan nyeri dan sebanyak $73 \%$ dari total keseluruhan memiliki tingkatan nyeri Kellgren-Lawrence sebesar 2 atau 3. Sebanyak 52\% tidak aktif dalam kegiatan fisik, dan $42 \%$ rajin aktivitas fisik. Secara keseluruhan terjadi peningkatan pemulihan yang ditunjukkan dengan nilai $\mathrm{p}=0,014$ serta WOMAC $-9,65$ sehingga dapat disimpulkan bahwa injeksi intra-artikular dengan dekstrosa hipertonik dapat memberikan peningkatan yang lebih baik pada fungsi dan kualitas hidup seseorang jika dibandingkan dengan normal saline. Selain lebih baik dari segi manfaat, penggunaan injeksi dekstrosa hipertonik juga memiliki harga yang terjangkau. ${ }^{5}$

Literautur ke-3 oleh Rabago et $\mathrm{al}^{8}$ pada tahun 2010 dan dipublikasikan dalam jurnal Primary Care - Clinics in Office Practice di Amerika Serikat dengan judul Prolotherapy in primary care practice. Dalam literatur ini disebutkan bahwa pasien menerima 3 sesi injeksi dari proloterapi dengan dekstrosa $10 \%$ dan lidokain maupun dengan air bakteriostatik. Dalam uji coba klinis ini dilaporkan bahwa terjadi peningkatan bermakna dalam penanganan nyeri, bengkak, episode gesper, maupun kemampuan bergerak. Setelah dalam 12 bulan melakukan peninjauan, hasil radiologi menunjukkan jarak antar sendi yang semakin bekurang dan meningkatkan ketebalan kartilago.

Literatur ke-4 oleh Hauser dan Cukla ${ }^{9}$ 
pada tahun 2009 dan dipublikasikan dalam jurnal Journal of Prolotherapy di Amerika Serikat dengan judul Standard clinical $x$-ray studies document cartilage regeneration in five degenerated knees after prolotherapy. Pada penelitian ini terdapat 3 pasien yang diberikan injerksi proloterapi berupa dekstrosa $15 \%$ dan sarapin $15 \%$. Injeksi proloterapi yang diberikan pada setiap kunjungan sekitar 5cc sampai 10cc, dan tiap 10cc injeksi ditambahkan juga glukosamin sulfat sebesar 400mg. Sekitar 30cc sampai 40cc total injeksi proloterapi yang diberikan pada pasien dalam satu kali kunjungan dan sama dengan 20 sampai 30 injeksi tiap lutut tiap kunjungan. Ketiga pasien yang menjalani terapi proloterapi, semuanya menyatakan bahwa terjadi peningkatan bermakna dalam kemampuan berjalan, bergerak (range of motion), tidak terasa nyeri (nilai $\mathrm{VAS}=0$ ), serta tidak adanya kekakuan dan bunyi suara kaki yang biasanya terdengar jika bergerak. Hal ini membuktikan bahwa telah terjadi regenerasi tulang rawan pada lutut disertai gambaran goto $\mathrm{X}$-rays yang membaik.

Literatur ke-5 oleh Reeves $\mathrm{DK}^{10}$ dipublikasikan dalam jurnal Pain Procedures in Clinicals Practice di Amerika Serikat pada tahun 2000 dengan judul Prolotherapy: basic science, clinical studies, and technique. Uji ilmiah dilakukan dengan pemberian injeksi glukosa pada 77 orang dengan rerata berat badan 193 pounds dalam 10 tahun terakhir. Terdapat 111 lutut dengan gambaran radiologik meliputi tanda-tanda osteoartritis serta 38 lutut yang sudah tidak memiliki kartilago telah menunjukan hasil yang baik. Pada kontrol 6 bulan pertama pemberian injeksi $(p=0,015)$ dan sampai 1 tahun (berkala 6 bulan setelah pemberian injeksi $9 \mathrm{ml}$ dekstrosa 10\%), menunjukkan hasil bermakna, dan dalam 1 tahun berikutnya tidak ditunjukkan adanya progresivitas dari osteoartritis dalam pemeriksaan X-rays.

Literatur ke-6 oleh Reeves et $\mathrm{al}^{11}$ dipublikasikan di dalam jurnal Physical Medicine and Rehabilitation Clinics of North America di Amerika Serikat pada tahun 2006 dengan judul Dextrose prolotherapy: a narrative review of basic science, clinical research, and best treatment recommendations. Langkah-langkah pemberian injeksi oleh Reeves et al, yaitu penggunaan dekstrosa 10\%, lidokain $0,075 \%$ dalam 0,2 dam 4 bulan, lalu dilanjutkan dengan pengamatan berkala setiap 6 bulan sampai 12 bulan yang menghasilkan peningkatan persentase kemampuan pasien berjalan dalam 0-6 bulan pertama penggunaan proloterapi, dan semakin membaik setiap saatnya. Rekapan analisis data yang telah dikumpulkan, menunjukkan bahwa dengan injeksi dekstrosa hipertonik periartikular dan intra-artikular untuk OA dalam skor komposit WOMAC $(0,81 \%$; $95 \%$ CL; 0,18-1,45\%; P 5. 012' 12553 6\%.

Literatur ke-7 oleh Sekeon dan Sharchis ${ }^{12}$ pada tahun 2019 dan dipublikasikan dalam Jurnal Sinaps dengan judul Peran dekstrosa hipertonik dalam tatalaksana proloterapi untuk osteoartritis lutut. Hasil pengamatan yang dikemukakan menyatakan bahwa proloterapi diindikasikan untuk nyeri punggung bawah (LBP), tendinopati, dan OA. Pemberian terapi berlangsung setiap 2 sampai 6 minggu. Pasien dengan terapi proloterapi mengalami pengurangan tingkat nyeri dalam 5-7 hari setelah pemberian suntikan. Penggunaan proloterapi dengan dekstrosa merupakan fokus yang dibahas. Konsentrasi dekstrosa yang digunakan intraartikular dapat bervariasi dari $12,5 \%$ sampai $25 \%$ yang paling sering $25 \%$ dengan volume 2 sampai $8 \mathrm{ml}$. untuk mencapai manfaaat terapeutik maksimum dibutuhkan 2 sampai 6 sesi proloterapi. Pasien dengan injeksi proloterapi peri- dan intra-artikular menunjukkan berkurangnya nyeri dan kecacatan lutut OA selama 5 bulan masa tidak lanjut. Dengan demikian, penggunaan injeksi proloterapi menggunakan dekstrosa hipertonik dapat dikatakan mampu untuk memberikan hasil bermakna dalam perbaikan nyeri pada pasien dengan OA lutut. Efek samping minimal mengangkat proloterapi menjadi pilihan yang tepat sebagai daya intervensi nyeri terutama pada tingkat primer.

Literatur ke- 8 oleh Hauser dan Hauser ${ }^{13}$ pada tahun 2011 dan dipublikasikan dalam Journal of Prolotherapy dengan judul Evidence-based use of dextrose prolo- 
therapy for muskuloskeletal pain: a scientific literature review. Dalam literatur ini, proloterapi merupakan highlight yang luar biasa jika ditinjau dari segi biaya dan manfaat. Proloterapi merupakan pengobatan yang dapat digunakan oleh semua golongan masyarakat, karena sangat ekonomis jika dibandingkan dengan tindakan operasi. Dekstrosa merupakan proliferan yang menjadi sorotan dalam literatur ini dan dalam prakteknya dekstrosa merupakan salah satu proliferan yang paling banyak digunakan. Dalam data terdapat sejumlah 44 kasus, dua dengan studi kontrol nonrandomisasi dan sembilan studi kontrol randomisasi. Terdapat pula 20 pasien yang mengalami OA lutut selama lebih dari 6 bulan dengan tingkatan nyeri Kallgren 2 dan telah diinjeksi dengan dekstrosa $15 \%$ sampai $25 \%$ selama 4 bulan. Hasil yang diperoleh yaitu pengurangan skala nyeri VAS dari 6,5 menjadi 2,65 ( $\mathrm{p}<0,05)$.

Literatur ke-9 oleh Wheaton dan Jensen ${ }^{14}$ pada tahun 2011 dan dipublikasikan dalam Journal of Prolotherapy dengan judul The ligament injury-osteoarthritis connection: the role of prolotherapy in ligament repair and the prevention of osteoarthritis. Dalam literatur ini terdapat sorotan terhadap biaya penatalaksanaan pada kasus OA lutut dengan prosedur pembedahan yang terhitung cukup mahal, dimana tindakan pembedahan merupakan opsi terakhir yang dapat diambil dalam penatalaksanaan OA. Tindakan operasi dinilai tidak dapat mencapai titik terapeutik terbaik, disebabkan dengan melakukan operasi maka akan ada jaringan yang dikeluarkan, dan hal ini dapat memengaruhi struktur anatomi awal seseorang, yang dapat mengubah susunan biomekanik sebuah jaringan sehingga dapat menimbulkan masalah yang baru. Selain harga, timbul masalah baru yaitu dengan operasi maka pasien membutuhkan waktu yang lebih lama bagi dirinya untuk dapat kembali melakukan kegiatan karena terbatas dalam pergerakan serta proses penyembuhan. Selain itu, literatur ini membahas mengenai pemilihan metode pengobatan lainnya yang tersedia. Berdasarkan analisis data yang tercantum, jika dibandingkan dengan injeksi salin pada ligamen, maka injeksi proloterapi lebih menunjukkan hasil yang bermakna terhadap ligamen, ketebalan ligamen, dan ukuran panjang ligament, serta kekuatan ligamen lebih meningkat pada pemberian injeksi proloterapi. Berbagai studi telah membuktikan bahwa dengan penggunaan injeksi proloterapi, perkembangan jaringan, ligamen dan sendi mengalami hasil yang memuaskan.

Literatur ke-10 oleh Arias-Vasquez et al ${ }^{15}$ pada tahun 2019 dan dipublikasikan dalam Advances in Rheumatology (London, United Kingdom) dengan judul Prolotherapy for knee osteoarthritis using hypertonic dextrose vs other interventional treatments: systematuc review of clinical trials. Pada jurnal ini terdapat berbagai perbandingan penggunaan injeksi proloterapi dengan dekstorsa hipertonik dan berbagai metode serta proliferan lainnya. Jurnal ini menyoroti kemampuan injeksi dekstrosa hipertonik dibandingan dengan metode maupun cairan injeksi lainnya. Berdasarkan analisis data yang telah dilakukan, ternyata penggunaan dekstrosa hipertonik (HDP) lebih efektif dalam mengurangi nyeri dan peningkatan fungsi jaringan jika dibandingkan dengan berbagai proliferan lainnya serta anastesi lokal. Berdasarkan sembilan studi yang telah dikumpulkan ternyata efek dan manfaat proloterapi mulai dirasakan pada bulan ke 23 setelah injeksi diberikan. Manfaatnyapun dapat bertahan lama. Enam studi lainnya menunjukkan bahwa hasilnya akan terlihat dalam 5-6 bulan setelah pemberian injeksi dan lima di antara studi ini menyatakan bahwa hasil yang baik dapat dirasakan dalam jangka waktu yang lama. Terdapat pula dua studi yang menyatakan bahwa injeksi dekstorsa hipertonik ini akan memberikan dampak positif setelah 12 bulan dan dapat bertahan selama satu tahun penuh sehingga perlu digarisbawahi bahwa penggunaan dekstrosa hipertonik memiliki manfaat jangka panjang. Untuk dosisnya, pada injeksi dekstrosa proloterapi ini sendiri dibutuhkan 10-25\% dekstrosa hipertonik dalam penggunaan intra-artikular. Untuk hasil yang maksimal dibutuhkan 2-6 bulan 
dalam setiap sesi, serta konsentrasi $25 \%$ untuk intra-artikular dan $15 \%$ untuk penggunaan tambahan pada bagian sendi. Data yang diperoleh menyatakan bahwa tidak terdapat efek samping berbahaya dalam pemberian injeksi dekstrosa hipertonik ini.

\section{BAHASAN}

Menurut Naseer et al, ${ }^{4}$ berbagai macam tatalaksana dapat dilakukan pada kasus OA lutut, dan menurut data yang diberikan, proloterapi merupakan salah satu metode yang sudah digunakan sejak 70 tahun silam. Penggunaan injeksi dekstrosa hipertonik pada daerah yang nyeri pada lutut dapat membuat respon inflamasi, diiringi oleh respon tubuh dalam menyintesis mediatormediator kimiawi yang dapat mempercepat proses regenerasi jaringan yang rusak, memperkuat jaringan ikat, serta meningkatkan biomekanik jaringan sekitar. Pada pengukuran berdasarkan WOMAC, didapatkan hasil bermakna dalam 4 minggu sejak injeksi pertama, dan tetap menunjukkan perkembangan yang progresif selama 1 tahun pemantauan. Dengan demikian, penggunaan proloterapi dalam penanganan $\mathrm{OA}$ lutut dapat dijadikan metode penatalaksanaan walaupun masih diperlukan penelitian yang lebih lanjut.

Sit et al $^{5}$ meneliti sejumlah total 205 partisipan dan mendapatkan 76 orang memenuhi standar kriteria dan dikelompokkan kedalam kriteria kontrol dan randomisasi, kemudian dibagi dalam 2 grup, masing-masing terdiri dari 36 orang dengan rerata umur 63,2 tahun, dan dengan mayoritas wanita sebanyak $73,2 \% ; 21 \%$ dengan kelebihan berat badan dan $46 \%$ obesitas. Durasi merasakan nyeri sekitar 8,9 tahun dan sebanyak $73 \%$ memiliki tingkatan nyeri Kellgren-Lawrence 2 atau 3. Sebanyak $52 \%$ tidak aktif dalam kegiatan fisik, dan $42 \%$ rajin beraktivitas fisik. Secara keseluruhan terjadi peningkatan pemulihan yang ditunjukkan dengan nilai $\mathrm{p}=0,014$ serta WOMAC -9,65 sehingga dapat disimpulkan bahwa injeksi intra-artikular dekstrosa hipertonik dapat memberikan peningkatan yang lebih baik dalam hal fungsi dan kualitas hidup seseorang jika dibandingkan dengan normal saline. Selain lebih baik dalam segi manfaat, penggunaan injeksi dekstrosa hipertonik juga memiliki harga yang terjangkau.

Raboga et $\mathrm{al}^{8}$ dalam uji coba klinis menyebutkan bahwa pasien menerima 3 sesi injeksi proloterapi dengan dekstrosa $10 \%$ dan lidokain maupun dengan air bakteriostatik dan melaporkan bahwa terjadi peningkatan bermakna dalam penanganan nyeri, bengkak, episode gesper maupun kemampuan bergerak. Setelah 12 bulan pengamatan, hasil radiologi menunjukan jarak antar sendi yang semakin berkurang dan meningkatnya ketebalan kartilago.

Pada penelitian oleh Hauser dan Cukla ${ }^{9}$ dilaporkan 3 pasien yang diberikan injerksi proloterapi dengan menggunakan dekstrosa $15 \%$ dan sarapin $15 \%$. Injeksi proloterapi yang diberikan pada setiap kunjungan sekitar 5cc sampai 10cc, dan tiap 10cc injeksi ditambahkan juga glukosamin sulfat sebesar $400 \mathrm{mg}$. Dari ketiga pasien yang menjalani terapi proloterapi, semuanya menyatakan bahwa terjadi peningkatan yang bermakna dalam kemampuan berjalan, bergerak (range of motion), tidak dirasakan nyeri (nilai VAS=0), serta tidak adanya kekakuan dan bunyi suara kaki yang biasanya terdengar jika bergerak. Hal ini membuktikan bahwa terjadi regenerasi tulang rawan pada lutut disertai gambaran goto X-rays yang membaik.

Reeves et al $^{10}$ melakukan sebuah uji ilmiah dengan pemberian injeksi glukosa pada 77 pasien yang memiliki rerata berat badan 193 pounds dalam 10 tahun terakhir. Terdapat 111 lutut dengan gambaran radiologi meliputi tanda-tanda osteoartritis serta 38 lutut yang sudah tidak memiliki kartilago telah menunjukkan hasil yang baik. Dalam kontrol 6 bulan pertama pemberian injeksi ( $p$ $=0,015$ ) dan sampai 1 tahun (berkala 6 bulan setelahnya pemberian injeksi $9 \mathrm{ml}$ dekstrosa $10 \%$ ), menunjukkan hasil yang bermakna, dan dalam 1 tahun berikutnya tidak tampak adanya progresivitas osteoartritis pada pemeriksaan X-rays.

Hasil penelitian Reeves et al ${ }^{11}$ dengan pemberian injeksi dekstrosa $10 \%$, lidokain $0,075 \%$ dalam 0,2 dan 4 bulan, kemudian 
dilanjutkan dengan pengamatan berkala setiap 6 bulan sampai 12 bulan mendapatkan peningkatan persentase kemampuan pasien berjalan dalam 0-6 bulan pertama penggunaan proloterapi, dan semakin membaik setiap saatnya. Rekapan analisis data menunjukkan injeksi dekstrosa hipertonik peri-artikular dan intra-artikular untuk OA dalam skor komposit WOMAC $(0,81 \%$; 95\% CL; 0,18-1,45\%; P 5. 012' 12553 6\%.

Sekeon dan Sharchis ${ }^{12}$ mengemukakan bahwa proloterapi dapat diindikasikan untuk nyeri punggung bawah (LBP), tendinopati dan OA. Pemberian terapi berlangsung setiap 2 sampai 6 minggu. Pasien dengan terapi proloterapi mengalami pengurangan tingkat nyeri dalam 5-7 hari setelah pemberian suntikan. Konsentrasi dekstrosa yang digunakan pada intra-artikular bervariasi dari $12,5 \%$ sampai $25 \%$ yang paling sering $25 \%$ dengan volume 2 sampai $8 \mathrm{ml}$. Untuk mencapai manfaaat terapeutik maksimum dibutuhkan 2 sampai 6 sesi proloterapi. Baik pasien dengan injeksi proloterapi perimaupun intra-artikular menunjukkan berkurangnya nyeri dan kecacatan lutut OA selama 5 bulan. Dengan efek samping minimal, maka proloterapi dapat menjadi pilihan yang tepat sebagai daya intervensi nyeri terutama pada tingkat primer.

Hauser et al ${ }^{13}$ menyatakan bahwa proloterapi merupakan pengobatan yang dapat digunakan oleh semua golongan masyarakat, karena sangat ekonomis dibandingkan dengan tindakan operasi. Dekstrosa merupakan proliferan yang paling banyak digunakan. Hauser et al mendapatkan 20 orang yang mengalami OA lutut selama lebih dari 6 bulan dengan tingkatan nyeri Kallgren 2 dan telah diinjeksi dengan dekstrosa $15 \%$ sampai $25 \%$ selama 4 bulan, dengan hasil yaitu pengurangan skala nyeri VAS dari 6,5 menjadi 2,65 $(\mathrm{p}<0,05)$.

Wheaton dan Jensen ${ }^{14}$ mengemukakan biaya penatalaksanaan pada kasus OA lutut dengan prosedur pembedahan yang cukup mahal, dan dinilai tidak dapat mencapai titik terapeutik terbaik disebabkan pada saat operasi terdapat jaringan yang dikeluarkan. Hal tersebut dapat memengaruhi struktur anatomi awal seseorang yang mengubah susunan biomekanik jaringan sehingga dapat menimbulkan masalah baru. Dengan dilakukannya operasi maka pasien membutuhkan waktu yang lebih lama untuk dapat kembali melakukan kegiatan. Wheaton dan Jensen juga membahas mengenai pemilihan metode pengobatan lainnya yang tersedia. Injeksi proloterapi bila dibandingkan dengan injeksi salin pada ligament, lebih menunjukkan hasil bermakna terhadap ligamen, ketebalan ligamen, ukuran panjang ligament, serta kekuatan ligamen.

Arias-Vasquez et al ${ }^{15}$ membandingkan penggunaan injeksi proloterapi dengan dekstrosa hipertonik dan berbagai metode serta proliferan lainnya. Hasil penelitiannya mendapatkan bahwa penggunaan dekstrosa hipertonik lebih efektif dalam mengurangi nyeri dan peningkatan fungsi jaringan dibandingkan berbagai proliferan lainnya dengan anastesi lokal, serta memiliki manfaat jangka panjang. Selain itu tidak didapatkan efek samping yang berbahaya dalam pemberian injeksi dekstrosa hipertonik.

\section{SIMPULAN}

Proloterapi merupakan solusi terbaik yang dibutuhkan dalam pengobatan OA dewasa ini terutama pada OA lutut. Proloterapi memberikan dampak penyembuhan secara langsung pada area yang mengalami cedera maupun nyeri melalui kerja sel-sel radang, makrofag dan sel-sel imun serta sitokin sehingga dapat bekerja lebih cepat untuk perbaikan daerah yang cedera.

\section{Konflik Kepentingan}

Penulis menyatakan tidak terdapat konflik kepentingan dalam studi ini.

\section{DAFTAR PUSTAKA}

1. Rachmawati E, Setia Pratama P, Machlaurin A. Studi penggunaan obat pada pasien osteoartritis usia lanjut di Instalasi Rawat Jalan Rumah Sakit dr. H Koesnadi Bondowoso Tahun 2013. e-Jurnal Pustaka Kesehat. 2018;6(3):408-15.

2. Maharani EP. Faktor-faktor risiko osteoartritis lutut [Tesis]. Semarang: Universitas Diponegoro; 2007. Available from: 
http://eprints.undip.ac.id/17308/1/Eka_P ratiwi_Maharani.pdf

3. Cianca JC, Jayaram P. Musculoskeletal injuries and regenerative medicine in the elderly patient. Phys Med Rehabil Clin N Am. 2017;28(4):777-794. Doi:10.1016/j.pmr. 2017.06.010

4. Naseer ZA, Okafor L, Kuwabara A, Khanuja HS. Nonoperative Treatment of Knee Arthritis (6th ed). Elsevier Inc., 2017. doi:10.1016/B978-0-323-400466.00121-0

5. Sit RWS, Wu RWK, Rabago D, Reeves KD, Cheong DCC, Hon BKY, et al. Efficacy of intra-articular hypertonic dextrose (Prolotherapy) for knee osteoarthritis: a randomized controlled trial. Ann Fam Med. 2020;18(3):235-42. doi:10.1370/ afm. 2520

6. Tyson WJ. Diagnosis and treatment. Br Med J. 1920;1(3096):619. Doi:10.1136/bmj.1. 3096.619-a

7. Hauser RA, Hauser MA, Baird NM, Martin DJ. Prolotherapy as an alternative to surgery: a prospective pilot study of 34 patients from a private medical practice. $\mathbf{J}$ Prolotherapy. 2010;2(1):272-81.

8. Rabago D, Slattengren A, Zgierska A. Prolotherapy in primary care practice. Prim Care - Clin Off Pract. 2010;37(1):65-80. Doi:10.1016/j.pop.2009.09.013

9. Hauser RA, Cukla JJ. Standard clinical x-ray studies document cartilage regeneratio in five degenerated knees after prolotherapy. J prolotherapy. 2009;1(1): 22-8.
10. Reeves DK. Prolotherapy: Basic Science, Clinical Studies, and Technique. Pain Proced Clin Pract. 2000:172-90. Available from: https://prolotherapy. com/Reeves_Prolotherapy\%20Basic20 Science\%20chapter.pdf

11. Reeves KD, Sit RWS, Rabago DP. Dextrose prolotherapy: a narrative review of basic science, clinical research, and best treatment recommendations. Phys Med Rehabil Clin N Am. 2016;27(4):783823. Doi:10.1016/j.pmr.2016.06.001

12. Sekeon SAS, Sharchis S. Peran dekstrosa hipertonik dalam tatalaksana proloterapi untuk osteoartritis lutut prolotherapy with hypertonic dextrose for chronic genu osteoarthritis. Sinaps. 2019;2(2): 30-4.

13. Hauser RA, Hauser MA. Evidence-based use of dextrose prolotherapy for musculoskeletal pain: a scientific literature review. J Prolotherapy. 2011;3(4):765-89.

14. Wheaton MT, Jensen N. The ligament injuryosteoarthritis connection: the role of prolotherapy in ligament repair and the prevention of osteoarthritis. J Prolotherapy. 2011;3(4):790-812.

15. Arias-Vázquez PI, Tovilla-Zárate CA, Legorreta-Ramírez BG, Fonz WB, MaganaRicardez D, Gonzales-Castro TB, et al. Prolotherapy for knee osteoarthritis using hypertonic dextrose vs other interventional treatments: systematic review of clinical trials. Adv Rheumatol (London, England). 2019;59(1):39. Doi:10.1186/s42358-019-0083-7 